\title{
PLURALITY OF RELIGION Future Challenges of Religion and Democracy in Indonesia
}

\author{
M. Zainuddin \\ UIN Maulana Malik Ibrahim, Malang - Indonesia | aldin_uin@yahoo.com
}

\begin{abstract}
Religious pluralism is a necessity. In Indonesia, there are six officially recognized religions, and some religious denominations. In the context of the challenges of democracy, religion in Indonesia faces daunting challenges This paper focuses on two challenges facing the religions related to the conception of democracy in Indonesia, namely the problem of understanding of religious teachings and politicization of religion. In the context of understanding religious teachings, believers interpret them correctly through exploring the substantial meaning, particularly in understanding religious doctrines regarding to the values of justice, human rights, democratization, and so forth. Furthermore, religion is understood as the truth rather than as an identity and a symbolic form. This is because understanding religion as an identity tends to create conflicts. In regard to the politicization of religion, religious followers provide a basis for common purpose and values that can help maintain a society's political life and national solidarity as well as control to the political system.
\end{abstract}

Keywords: Religion, plurality of religion, democracy, politics.

\section{Introduction}

Indonesia is a pluralistic society in terms of ethnic, linguistic, cultural or religious differences. According to Heldred Geertz, ${ }^{1}$ in

\footnotetext{
${ }^{1}$ Hamami Zada, "Agama dan Etnis: Tantangan Pluralisme di Indonesia," in Sururin and Maria Ulfa (eds), Nilai-Nilai Pluralisme dalam Islam (Jakarta: Nuansa-Fatayat NUFord Foundation, 2006), p. 184.
} 
Indonesia, there are more than three hundred ethnicities in which each has its own culture, and more than two hundred and fifty languages are used. In addition, almost all major world religions embraced by Indonesian people as a part of the variety of native religions themselves. Meanwhile Coward asserted, that pluralism is a phenomenon that cannot be avoided. Humans live in a pluralism and is part of the pluralism itself. ${ }^{2}$ However, religious plurality is inevitably also a challenge in the world today. It means, if the plurality of religion is not addressed properly and wisely, it could cause not only interreligious conflict, but also social conflict and disintegration. ${ }^{3}$

In the context of modern Indonesia, Abu Rabi'4 admitted that Islam has become a force in growing the value of religious pluralism since Indonesia's independence. However, according to him, its chance to become a social movement of anti-Christian sentiment remains wide open. Various trends and patterns of Islamic thought which emerged lately, indicating differences among Muslims in dealing with other religious communities. Therefore, according to Rabi', the growing religio-political aspirations will remain an opportunity for the growth of Islamic social movements which are difficult to uphold the values of tolerance, openness and democracy. Additionally, this challenge appears to be more evident with the development of post-modern religious discourse. Despite the role of religions are to promote unity from time to time, they also often encourage split rather than unified humanity. ${ }^{5}$

2 Harold Coward, Pluralisme dan Tantangan Agama-Agama (Yogyakarta: Kanisius, 1989), p. 167. See also Harold Coward, "Religious Pluralism and the Future of Religions," in Thomas Dean (eds), Religious Pluralism and Truth Essays on Cross Cultural Philosophy of Religion (New York: State University of New York Press, 1995), p. 45. Compare with Frans Magnis Suseno, "The Challenge of Pluralism," in Kamaruddin Amin et.al., Quo Vadis Islamic Studies di Indonesia? (Jakarta: Directorate of Islamic Higher Education, MORA Collaboration with Post Graduate Program UIN Alauddin Makassar, 2006), p. 13.

3 In this paper, I use the term "plurality" instead of "pluralism", since they have different definition. Plurality means reality-the true reality, while pluralism is a religious thought. for further insight, see M. Zainuddin, "Pluralisme dan Dialog Antaragama," in Journal of Media Philosophica-Theologia, IPTH Malang, 5, 1 (March 2005).

${ }^{4}$ Abu Rabi', "Christian-Muslim Relations in Indonesia: The Challenges of the TwentyFirst Century," in Studia Islamika (Jakarta: IAIN Syarif Hidayatullah, 1998), p. 2.

${ }^{5}$ Since the decade of 1980 s to the present, initiative to realize inter-religious harmony and dissemination of understanding this plurality has been carried out by the religious 
From a historical perspective, violence and intolerance occurred from the followers of monotheistic religions. The question is, then, why monotheistic religion is inherently intolerant and violent? According to Rodney Stark, ${ }^{6}$ the claim of monotheism which is particularistic-subjective 7 has frequently lead to conflict. Stark further highlighted that the subjectivism of the believers of monotheistic religions (Jewish, Christian and Muslim) look down on other religions. His research concluded that the differences of religion in societies rooted in social niches-groups of people who share preferences pertaining to religious intensity. ${ }^{8}$ According to Stark, the plurality of religions is a necessity and it can be stable if none of single-religious organization is too dominant.. Further, he came to the conclusion that

elites, young intellectuals, and the government itself. For example, a dialogue organized by the International Conference on Religion and Peace (ICRP) initiated by Djohan Effendi and his colleagues at the Institutional Dialogue, the dialogue between delegates of various religious organizations, involving religious councils recognized by the government, such as the Indonesian Ulama Council (MUI), Association of Indonesian Churches (PGI), the Bishops' Conference of Indonesia (KWI), Parisada Hindu Dharma and Perwalian Umat Budha Indonesia (WALUBI). Dialogue on transformative discourse is often done by intellectuals or NGO's such as the Institute for Interfaith Dialogue in Indonesia or Interfaith Dialogue (Interfidei/DIAN), Paramadina, Institute of Islamic and Social Studies (LKiS) in Yogyakarta, the association of Pesantren and Community Development (LP3M) in Jakarta, Interreligious Dialogue Society (MADIA), and others. But in reality, the tension and unrestness caused by religious sentiments (Islam-Christian) in some areas, such as in Situbondo, Tasikmalaya, Ketapang, Kupang, Ambon, Poso, Maluku and so on have resulted in the destruction of worship places, such as mosques, prayer rooms, and churches. Yet, the Government's efforts in resolving the conflict in Poso, which gave birth to so called Malino I and Malino II Negotiations. Malino II negotiation was expected to generate significant benefit for peace and harmony among believers in Indonesia. However, this effort, as we have seen together, was unable to overcome and prevent the re-emergence of inter-religious conflict. This phenomenon indicates a disparity (gap) between the ideals of religion (das sollen) as the Lord's holy teachings and messages with the empirical reality that exists in society (das sein).

${ }^{6}$ Rodey Stark, One True God: Resiko Sejarah Bertuban Satu, translated by M. Sadat Ismail (Yogyakarta: Qalam, 2003), pp. 171-3, and p. 183.

7 According to John Hick, the absolute claim is proclaimed all religions; Islam, Christian, Hindu and Jew. see John Hick, Problem of Religious Pluralism (London: The Macmillan Press, 1985), p. 46; David Tracy, Plurality and Ambiguity, Hermeneutic, Religion, Hope (Chicago: University of Chicago Press, 1987), pp. 89-90.

${ }^{8}$ Stark seems to persuade people to advocate the view of pluralism. Personally, I see that there is no harm in the absolute claim, but it would be problematic if the absolute claim followed by looking down and compelling others to join another religion. 
religious conflict will be heightened if some powerful and particularistic religious organizations coexist. ${ }^{9}$

Thus, in this context, there are at least two problems ahead of the believers: first is the problem of understanding of religious teachings, and the second is the problem of politicization of religion. This paper aims to address these two problems.

\section{The Understanding of Religious Teachings}

Today, the problem of universal humanity is the main challenge faced by believers. Therefore, religion is supposedly able to answer the problems of humanity as a whole, including justice, welfare fulfillment, environmental protection, and so on. Otherwise, then religion will lose its influence.

Religious teachings and its substantial meaning must be understood and explored correctly. . Contemporary issues such as justice, human rights, democratization and all efforts of advocating public interest are some indicators of the successful religious propagation. It is due to the fact that the religious dimension is not only theocentric dimension, but also loaded with the anthropocentric dimension. Religion is revealed by God to humans, while humans depend on macro-nature.

In daily practices, it is often found that faith and good deeds are unbalanced. In other words, the internalization of the faith values is often separable from its social roles. This is because faith in religion does not relate to the empirical reality. Historically, the faith value (orthodoxy) and the charity value (orthopraxis) in religion have experienced too many contradictions and gaps. As a result, such imbalance (gap) had led to criticism of the religion and its adherents, in which they are described as: the religion self-centered and individualist, the religion is just replete with sacred doctrine, ritual practice, holy sayings, and so on. Whereas, religion is known as a carrier of grace and savior of people. Even, normatively, religion is considered as a social control, education, unifying tools.

In his work Spiral of Violence, Dom H. Camara, ${ }^{10}$ an activist and archbishop, called for all religious communities to unite and reopen their holy book to find the teachings of universal humanity in order to

\footnotetext{
${ }^{9}$ Stark, One True God, p 76 and p. 181.

${ }^{10}$ Dom Heder Camara, Spiral Kekerasan (Yogyakarta: Pustaka Pelajar, 2000).
} 
fight injustice. Asghar Ali Engineer, ${ }^{11}$ a Muslim activist, urged the need to fight serious problem of bipolarity between spiritual-material aspects of human life by rearranging the fair and egalitarian social life. According to Ali, the true believers are not those who recite shahadah, but those who uphold justice and fight for oppressed groups (almustad'afin). Therefore, justice must be pursued to attain peace and the integrity.

The concept of the prophecy actually contains the notion of the real enemy of religion is injustice and social inequality. Both are the responsibility of all religions as they do not endorse any form of injustice. Here the universal truth of religion lies.

In Islam, there is no dichotomy between religious and social domain. Islamic values are basically-according to Kuntowijoyo's term ${ }^{12}$ - is an inclusive term for structuring the social life, politics, economics, and culture. Therefore, the biggest task of Islam is to conduct a social and cultural transformation in accordance with the values of Islam which is humanist (read: rahmah).

In Islam, those who ignore social inequality (indifference to the poor, orphans, and displaced or oppressed people) are called as liars and traitor of religion. ${ }^{13}$ Further, those who accumulate wealth without giving benefits to the others are called as the enemy of religion. ${ }^{14}$ Therefore, it can be understood why the Quraish desperately opposed the Prophet Muhammad Saw, because he was considered to eradicate the practices of wealth monopoly by the Arab conglomerate at that time.

Essentially, religion should be able to answer the complex challenges across the time. In order that adherents keep believe in it. Parts of challenges are understanding religion and politicization of religion. Meanwhile religious plurality can be a treasure of the nation if it is understood as a gift of God by means of cooperation to build unity among religious believers in order to realize the prosperity of the world. Then the religion will be able to answer both current and future challenges.

\footnotetext{
${ }^{11}$ Asghar Ali Engineer, Islam Pembebasan (Yogyakarta: LKiS, 1993), p. 29 and p. 80.

12 Kuntowijoyo, Paradigma Islam, Interpretasi Untuk Aksi (Bandung: Mizan, 1991), p. 167.

${ }^{13}$ See, Al-Qur'an, al-Máúun.

${ }^{14}$ See, Al-Qur'an, al-Humazah.
} 
However, current phenomenon shows that religion is more oriented to the status quo rather than humanitarian mission. Religion is more likely based on the interests of the officials or formal religious leaders. Therefore, the notion of religious doctrines must be understood correctly. It means that religion is the integration between normative and practical dimension or between esoteric and exoteric aspects (samawat wa al-ard). It is like cool and soothing water that flow down from the mountain to the lake. This means that religion should be social values for the human.

In line with this, the reorientation of religious education in schools is extremely urgent to build social awareness. In addition, it can be seen from this study that the advantages and shortcomings of the religious educational model imposed by the Ministry of Religious Affairs thus far. So that, it is necessary to have further research on the messages that define elementary humanitarian issue contained in textbooks. This issue must be addressed immediately, so that religious doctrines become increasingly more significant for the creation of a harmonious life of the nation. In other words, the emphasis of religion is not only focusing on the normative-verbal aspects, but more importantly is on the spirit-the spirit of religion-namely the establishment of morality and compassion. Through the last educational model, students will be expected to be an individual who acquires ideal personality, high spirit of solidarity, honesty, fairness, and, thus who will be far from the violent act and social conflict. The objectives of this kind of education would also be clear when faced with the complexity and plurality of religions.

Here the plurality of religions in Indonesia should be a constructive-transformative force in our educational model. This model can be inserted or integrated in the national curriculum from elementary schools until university. The national curriculum should quality as a curriculum which is based on human values and spirituality.

\section{Politicization of Religion}

In The New Cold War: Religious Nationalism Confront in The Secular State, Mark Jurgens Meyer ${ }^{15}$ said that the New World order which

\footnotetext{
15 John Naisbit and Patricia Aburdene in their Megatrend 2000 also predict the emergence of ten trends in the decade of 1990s, including the revival of the religions, moreover after the collapse of communist ideology in the Eastern Europe, mainly Soviet. Is it the end of ideology as has been predicted by Daniel Bell's? The next question
} 
replaces the bipolar-forces of the Old Cold War is not only characterized by the emergence of new economic powers, the collapse of the ancient kingdoms and weakening communism, but also by the rise of parochial identities based on ethnicity and allegiance to religion. ${ }^{16}$

Meanwhile, E. Marty and Appleby ${ }^{17}$ asserted that the collapse of communism in Western Europe and the ruin of the Marxist ideology in the Soviet Union in the 1990s encouraged the speculation among political analysts about the "new enemy" that will be faced by America. What ideological force that would be an obstacle for the establishment of liberal democracy in Western countries towards the development of a global world? The answer is religious fundamentalism.

In this context, Bassam Tibi ${ }^{18}$ in The Challenge of Fundamentalism: Political Islam and the New World Disorder explained that Islamic fundamentalism is only one kind of global phenomenon in the world politics and an ideological symptom of the "clash of civilizations". According to Tibi, fundamentalism is not a solution, but it tends to easily create chaos. This is because it would constantly prompt the conflict and sharpen the cultural fragmentation. Tibi has rejected the politicization of religion carried out by fundamentalist groups. The reason is that fundamentalism seems to be a more political ideology rather than a purely religious phenomenon.

How is the relationship between Islamic fundamentalism and violence? Some Muslim authors are apparently critical of Islamic fundamentalism. Tibi, for instance, suggests that Islam as a religion is not a threat, but Islamic fundamentalism as a threat is true. In line with Tibi, regarding to the confrontation between Islamic and Western

is whether religion has become a real alternative today, upon the emerging polemic about religion post-ideology?

16 Jurgensmeyer does not use the term fundamentalism, rather he preferred the term "religious nationalism". It is based on three reasons: first, the term fundamentalism seems to be more an accusation than description; second, fundamentalism is a category that is not appropriate to make comparisons between cultures; third, fundamentalism describes the demeanor that solely motivated by religious beliefs rather than broad issues about the nature of society and the world.

${ }^{17}$ E. Marty and Appelby, Fundamentalism and the State (Chicago: University of Chicago Press, 1991).

18 Bassam Tibi, The Challenge of Fundamentalism: Political Islam and the New World Disorder (California: University of California Press, 1998), pp. 12-13. 
civilization, Soroush ${ }^{19}$ was worried about the use of Islam as an identity. It is because Islamic identity, according to Soroush, is a warloving Islam, not peace-loving Islam. ${ }^{20} \mathrm{He}$ asserted that. it is true that Muslims have an identity and civilization, but they may not use Islam for the sake of identity and the civilization. Islamic should be understood as a truth, because Islam as a truth can coexist with other truths, while Islamic identity tends to be hostile.

The above issues are rooted from the classic debate regarding to whether Islam is both a religion and a political ideology or it is only a religion. Some Muslims firmly believe that Islam cannot be separated from politics, namely Islam is both a religion and politics (al-Islam Din wa Daulah). Others, argue that Islam is merely a religion, separated from matters of politics. Such groups of political Islam (al-Islam al-

19 Abdul Karim Soroush, Menggugat Otoritas dan Tradisi Agama, translated by Abdullah Ali (Bandung: Mizan, 2003), pp. 32-34.

${ }^{20}$ Mohammed Arkoun, a modern Islamic scholar, tried to give the term fundamentalism with different expressions, namely: Ușülawiy or Usülawiyah (using the letters w/wawu). Arkoun uses two new terms: Islamaniy or Islamawiyah to Islamism and Usülawiy or Usülawiyah to fundamentalism. According to Arkoun, Islamawiy or Islamawiyah means the excessive use of belief or thought. The term Islamiy (without w) means the simplicity of attitudes that remain flexible as well as inclusive in term of both thought and intellectual. According to Arkoun, Islamawiy or Islamawiyah fighter uses its lexical/literal meaning for political purposes and taking elements from here and there to mobilize the people. Besides the terms Islamiy, the term Ușuliy, according to Arkoun, refers to something that is positive and encourages us to study the history of Islamic thought at

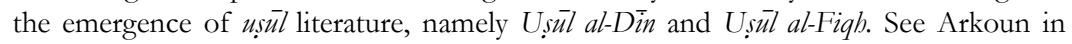
Jauhari et.al. (eds), Membongkar Wacana Hegemonik dalam Islam dan Modernisme (Surabaya: al-Fikr, 1999), pp. 67-68. According to Arkoun, both Western observers and observers from Islam themselves have incorrect view on the discourse of fundamentalism. The Orientalists and the West, in general, always view Islam as a religion of violence and synonymous with the terrorist movement. Therefore, the term of fundamentalism must be dismantled or redefined. The incorrect naming of an Islamic movement is fatal to Islam itself. Islamic fundamentalism that has been associated with violent movements, terrorism or insurgency was a big mistake and has reduced the value of Islam itself. According to me, the term fundamentalism and radicalism are more appropriately awarded to Islamic thinkers such as Mohammed Arkoun, Hassan Hanafi, Al-Naim, Ashgar Ali, Nurcholish Madjid, Abdurrahman Wahid, who have been referred to neo-modernists, because they have fundamental Islamic thought and in its depth, not to a group of people whose thought is still unknown and have not mastered many treasures of classical Islam. Therefore, fundamental thought is more identical to the substantial idea. By doing so, the fundamentalist movement is the movement of inclusiveness, not vice versa, which has been defined as exclusive and textualscripturalist. 
Siyasi) are represented by Ayatollah Khomeini which is easily identified through his popular work, that is Kashf al-Gayb and his organized revolutionary movement. While apolitical Islam (al-L̄a siyasiy) is represented by Ali Abd al-Räziq with his popular work al-Islam wa $U_{s ̧} \bar{u} l$ al-Hukm and its alike. ${ }^{21}$ Two views above are also marked the religious life in manyparts of the world, including Indonesia. In Indonesia, Islamic identity is represented by groups of Islamic organizations such as FPI (Islamic Defender Front), HTI (Indonesian Liberation Party), and PKS (Social Welfare Party), while the non-political Islamic groups are represented by NU and Muhammadiyah.

\section{Religion and Democracy in Indonesia}

Normatively speaking, policy on religious tolerance has been formulated in the legislation, but on practical level, the ideal formulation seems cannot be completely implemented by some of communities in everyday life. It can be indicated by the persistence of religious conflict and disorder.

How does the experience of democracy in the context of religious freedom in Indonesia? Yet, the freedom of religion in Indonesia has remained many problems. It can be seen from some clerics' statements that have encouraged government to ban a minority Islamic sect labeled "deviant' and "heretical", such as Abmadiyah. Wahid Institute recorded that there were 158 cases of human rights violations during the year 2014. The case is the first and highest, religious-based violence as many as 55 cases. Second, as many as 50 cases of religious apostasy. Third, the relationship among religious believers as many as 29 cases. While the forms of violations of religious freedom there were 280 cases. The first case, and the highest, 43 cases of religious apostasy. Second, physical assault and torture as many as 35 cases. Third, restrictions on freedom of expression as many as 27 cases. $^{22}$

\footnotetext{
${ }^{21}$ For this issue, see John J. Donohue and john L. Esposito, Islam in Transition; Muslim Perspectives (Oxford: Oxford University Press, 2007); Dale F. Eicklelman and James Piscatori, trans., Ekspresi Politik. Muslim (Bandung: Mizan, 1998).

22 Total findings of violations against Freedom of Religion and Belief throughout 2014 was 158 cases. The second daughter of former President Abdurrahman Wahid was reporting, from the side of the offender, the state as an actor Freedom of Religion and Belief violations recorded in 80 cases. In 78 other cases do non-state actors. The involvement of developing countries due to the local government or the security forces were decisions when actors intolerant minority report which was considered disturbing environment. "In general, the number of violations decreased Freedom of
} 
Those striking cases are major challenges for Indonesian religious life that should be addressed. . Clearly, religion should be a driving force of democracy, because it is believed that all religions have a common mission to uphold universal values of human rights and human dignity, which is part of the democratic idiom. Religious diversity in the world is a fact and as a rule of Allah (sunnah Allah). In addition, it must be understood, that all religions called on the goodness and harmony.

However, most believers as well as religious leaders often ignore that they live in Indonesia, which has Pancasila as an umbrella ideology. Therefore, there is no reason to force anyone to act in a manner contrary to his own religions and beliefs. Additionally, Prophet Muhammad as a religious leader and state in Medina at that time never did coercion and violence against non-Islamic faiths. ${ }^{23}$. Theologically, every religion is different from one another, but it does not mean that all religion allow their believers to commit violence as all religions have value frameworks regarding humanity, social justice, honesty, and so forth.

Actually, religious diversity as a fact of national life is likened to living in the middle of the traditional market. In this market a wide range of merchandise marketed by various sellers of diverse religions and faith. It is hardly ever any conflicts because of the merchandise. The buyers may do not think who is selling the merchandise, whether Muslims or Christians (except related to halal or ḥaram goods). People actually prefer to buy goods to the sellers who can satisfy customers and they have a good quality merchandise.. Like a market, religious people are required to best serve other people and should compete for doing the common good (fastabiq al-khairat). In a social perspective, pluralism counteracts the domination and hegemony groups or religious sects, as well as negating the concentration of social power on one group or sects. While the perspective of cultural pluralism prevents the loss of sects due to religious schools destroyed by the

Religion and Belief. In 2013, The Wahid Institute recorded 245 cases. However, this figure does not show any increase in the state's responsibility in solving the fundamental problems of Freedom of Religion and Belief,"' said former Secretary General of the Party of National Revival (PKB) (http://www.tabloidpodium.com/berita-catatan-the-wahid-institut-tentang-kebebasan-beragama.html).

${ }^{23}$ Pulungan, Prinsip-prinsip Pemerintahan dalam Piagam Madinah Ditinjau dari Pandangan alQur'an (Jakarta: Rajawali Press, 1994), p. 32. 
main hegemony, and on the other side of arrogance counteract mainstream religious denominations that are often tempted or historically-empirical abuse and oppression flow or any other religion. While political pluralism could be the basis for the guarantee of freedom of belief and expression without fear of threats of violence for their management agencies of conflict of interest and interreligious. ${ }^{24}$

Freedom of religion in the context of Indonesia is stipulated in the legislation as "free to choose and embrace a particular religion" and it does not recognize atheism and agnosticism, because Indonesia is a country based on the Pancasila and Oneness of God. How is the relation between religion and democracy? If it is viewed from the normative base, religion and democracy is totally different. Religion is derived directly from the revelation of God, while democracy is derived from human thoughts.

Nevertheless, according to Aswab Mahasin, ${ }^{25}$ there is no obstacle for religion to coexist with democracy. This is because there are many verses in the Qur'an mentioned the main principles of democracy, ${ }^{26}$ such as as-shüra (delebration), al-musawwāh (equality), al-'adalah (equity), al-amānah (trust), al-masüliyyah (responsbility) and al-hurriyyah (freedom).

The question is, then, how is the reality of democracy in the Islamic world? This problem was answered by Huntington and Fukuyama ${ }^{27}$ by asserting, "the reality of Islamic society is not compatible with democracy".

Actually, in the history of Islam, there was authoritarianism wrapped in religiosity (the spirit of Islam), as carried out by caliphates Banu Umayyads and Abbasids. In addition, it must be admitted that the post era of the Prophet Muhammad and al-Khulafa al-Rashidūn

\footnotetext{
${ }_{24}$ M.M. Billah, "Pluralitas Agama di Indonesia: Memilih Kerangka Pemahaman atas Keberadaan Aliran Keagamaan dari Perspektif Teologi dan HAM," in Lutfi Mustofa (ed.) (Malang: LKQS UIN Malang, 2007), p. 47.

25 Imam Aziz, et.al. (eds.), Agama, Demokrasi dan Keadilan (Jakarta, Gramedia, 1999), p. 30.

26 Among others al-Quran, Ali Imrān: 159 and al-Shurā: 38 (which explains about deliberations); al-Mäidab: 8 and al-Shurä: 15 (on justice); al-Hujurät: 13 (on equality); alNisăa 58 (on trust); Ali Imrān: 104 (on freedom of criticism); al-Nisa': 59, 83 and alShurā: 38 (on free speech). See Abd al-Baqi, al-Mu'jam al-Mufahras li alfädh al-Qur'an alKarim (Libanon: Dar al-Ihya' al-Turāth, n.d.).

${ }^{27}$ See Aswab Mahasin in Aziz, Agama, Demokrasi dan Keadilan.
} 
democracy was often used as a scapegoat. Mahasin's observation in some parts of the Arab countries reveals that Islam as if imposed corrupt and authoritarian kings. However, the similar reality has also been experienced by other religions. The Catholic Churches, for example, remained indifferent when the French revolution took place. Because of that attitude, then Catholicism referred to as undemocratic. Protestants, which at the beginning of its emergence, also experienced the same thing, and with the reform of Martin Luther, Christians sided with the economic elites, to the detriment of the position of the peasants and workers. No wonder why, then, Christians were called undemocratic. Therefore, Huntington and Fukuyama's statement that, empirically, Islam is not compatible with democracy actually does not happen to the Muslim community only, but also to other religions. Therefore, the attention to the relationship between religion and democracy in a social community should involves many variables, including the non-religious independent variables.

Indeed, there is a problematic gap between the idealistic values of our religion and the empirical reality of our daily lives. In addition, the major problems are faced by multi-cultural society today not far from these themes. The religions in the world today are faced with the challenge of universal humanity. Can religion answer this universal human problem, including Islam?

Normatively, some verses of the Qur'an call us to be faithful man and then charity. In the verse of al-Baqarah ${ }^{28}$ is mentioned that in order to be faithful man, first of all he should believe in the unseen, establish prayer, and spend out of what we have provided for them .

It can be seen from the paragraph the inter-relation of tree concepts: faith-prayer-alms, while in other formulations, we also know faithful man trilogy, namely faith, science, and charity. It can be conclude that faith leads to charity or action. Thus, Islam makes tawhid as the center of all value orientation, while at the same time sees humans as the purpose of the transformation of values. Regarding to this, Islam is called the religion of rahmatan li al-'alamin (blessing for all creation) beyond sectarian beliefs. In the verse of al-Anbiy $a^{\prime}, 107$ Allah confirms, that the Prophet Muhammad was not sent to this world except as a mercy for all creatures of the universe, including Jinn's. ${ }^{29}$

\footnotetext{
28 See al-Baqarah: 3.

${ }^{29}$ See al-Anbiyā: 107
} 
It is stated in Tafsir al-Munir by Wahbah Al-Zuhaili, ${ }^{30}$ that rabmatan li al-älamin is included mercy for non-Muslims. Meanwhile, in a very popular hadith mentioned that the Prophet was sent to this world is to enhance human morality (al-akbläq al-karimab). Migration (hijrah) performed by the Prophet Muhammad Saw to Medina was to build community-oriented development which is free from exploitation, domination and injustice.

The concept of al-akblaq al-karimah or good morality is often understood as mere courtesy only. Actually al-akblaq al-karimah covers all kind of good behaviors, including maintaining the balance of the universe such as ecological issues, human rights, justice, democratization, social inequality and so on. Similar with the word al$\bar{a} \bar{d} \bar{b}$. It is often understood as manners or decorum students with teachers or children and parents. Meanwhile it has an extension of meaning, namely $t a^{\prime} d \bar{i} b$ which means developing civilization as portrayed in the representation of the Prophet Muhammad Saw in the world in order to edify mankind. This morality is commensurate with Ibsān as the continuation of Islam and faith.

So the concept of morals is more than just a human relationship, but it is the regulation between man and God, among mankind, and human with other creatures. This concept is explained in the al-Qur'an (al-Qașas: 77):

"And seek by means of that treasure which Allah has bestowed to you, the home of the Hereafter, and forget not your share in the world and do good as Allah has done good to you and seek not mischief in the land. Undoubtedly Allah loves not the mischief-makers".

The verse describes three important dimensions of human life that must be protected, namely the theological, sociological and cosmological dimension. Additionally, Islam has been talking about "relational regulation" between khäliq and makblüq and "intermakbluq". This is actually the ethics of Islam (al-akblaq al-karimab).

Basically, Islam is more than a formal religion. It is the great treatise for social transformation and challenges for vested interest has been demonstrated by its emphasis on prayer and charity. In many

30 See Wahbah al-Zuhaili, Tafsir al-Munir; fi al-'Aqidah wa al-Shari'ah wa al-Manhaj (Beirut: Dār al-Fikr al-Mu'asir, 1991). 
verses of the Qur'an, prayer is never mentioned without being accompanied by charity. People are always accumulate wealth and do not want to spend their zakāh branded as arrogant (al-mustakbirin).

Asghar Ali ${ }^{31}$ said that when the Qur'an clearly condemned the oppression and injustice, attention to a form of egalitarian social order cannot be denied. Therefore, according to Ali, verse the Qur'ran also has socio-economic connotations.

Religion itself has a role as to guiding human to the right path that contains rules concerning the human relationship with God, with fellow human beings and with surrounding nature. These rules are expected to be able to maintain world peace, and thus human beings would be able to pursue happiness not only in the world, but also in the hereafter. Logically, in the context Indonesia, religion is supposed to guarantee peace and social order, because Indonesia is a religious nation and our state which is not a secular country. But, why the reality is just the opposite? Where is the role of religion as a spirit and driving-force of the development? This is the challenge that people face currently. Therefore, in my opinion, religion will be able to be a purely positive force in the world today, if the teachings are implemented in the community by promoting the ethics and social values, for example, developing the values of democracy, human rights, universal humanity, and so on.

\section{Conclusion}

The plurality of religions is a necessity, but in doing so as a challenge to democracy in Indonesia. Religious plurality on the one hand has the potential harmony, and also has the potential for conflict on the other hand. In this context, there are at least two problems faced by adherents to the religion in the face of the challenges ahead: first, the problem of understanding of religious teachings. Second, the problem of politicization of religion.

In regards to understanding its teachings, religious doctrines must be understood correctly through exploring its substantial meaning. Contemporary issues concerning justice, human rights, democratization and all kinds of siding society should be an indicator of the successful religious propagation $(d a w a)$. Simultaneously, the reorientation of religious education in schools for the creation of social awareness is also very urgent. Furthermore, we have to avoid the

${ }^{31}$ Asghar Ali, Islam Pembebasan (Yogyakarta: LKIS, 1993), p. 89. 
politicization of religion. In short, Islam as a religion should be the control within the life of the nation.

Meanwhile, religion must be understood as the truth than as the symbolic forms. Islamic identity should be subject to Islam as the truth, because Islam as the truth can coexist with other faiths, while Islam as an identity tends to promote conflict. []

\section{References}

\section{Books and Articles}

al-Baqi, Abd. al-Mu'jam al-Mufahras li alfädh al-Qur'än al-Karim. Libanon: Dar al-Ihya' al-Turāth, n.d.

al-Zuhaili, Wahbah. Tafsìr al-Munir; fi al-'Aqidah wa al-Shari'ah wa alManhaj. Beirut: Dār al-Fikr al-Mu'asir, 1991.

Aziz, Imam et.al. (eds.). Agama, Demokrasi dan Keadilan. Jakarta, Gramedia, 1999.

Billah, M.M. "Pluralitas Agama di Indonesia: Memilih Kerangka Pemahaman atas Keberadaan Aliran Keagamaan dari Perspektif Teologi dan HAM." in Lutfi Mustofa (ed). Malang: LKQS UIN Malang, 2007.

Camara, Dom Heder. Spiral Kekerasan. Yogyakarta: Pustaka Pelajar, 2000.

Coward, Harold. "Religious Pluralism and the Future of Religions." in Thomas Dean (eds.). Religious Pluralism and Truth Essays on Cross Cultural Philosophy of Religion. New York: State University of New York Press, 1995.

-. Pluralisme dan Tantangan Agama-Agama. Yogyakarta: Kanisius, 1989

Donohue, John J. and john L. Esposito. Islam in Transition; Muslim Perspectives. Oxford: Oxford University Press, 2007.

Eicklelman Dale F. and James Piscatori, trans. Ekspresi Politik Muslim. Bandung: Mizan, 1998.

Engineer, Asghar Ali. Islam Pembebasan. Yogyakarta: LKIS, 1993.

Hick, John. Problem of Religious Pluralism. London: The Macmillan Press, 1985 
Jauhari et.al. (eds.). Membongkar Wacana Hegemonik dalam Islam dan Modernisme. Surabaya: al-Fikr, 1999.

Kuntowijoyo, Paradigma Islam, Interpretasi Untuk Aksi. Bandung: Mizan, 1991.

Marty, E. and Appelby. Fundamentalism and the State. Chicago: University of Chicago Press, 1991.

Pulungan. Prinsip-prinsip Pemerintahan dalam Piagam Madinah Ditinjau dari Pandangan al-Qur'an. Jakarta: Rajawali Press, 1994.

Rabi', Abu. "Christian-Muslim Relations in Indonesia: The Challenges of the Twenty-First Century." Studia Islamika. Jakarta: IAIN Syarif Hidayatullah, 1998), p. 2.

Soroush, Abdul Karim. Menggugat Otoritas dan Tradisi Agama. translated by Abdullah Ali. Bandung: Mizan, 2003.

Stark, Rodey. One True God: Resiko Sejarah Bertuhan Satu. translated by M. Sadat Ismail. Yogyakarta: Qalam, 2003.

Suseno, Frans Magnis. "The Challenge of Pluralism." in Kamaruddin Amin et.al. Quo Vadis Islamic Studies di Indonesia?. Jakarta: Directorate of Islamic Higher Education, MORA Collaboration with Post Graduate Program UIN Alauddin Makassar, 2006.

Tibi, Bassam. The Challenge of Fundamentalism: Political Islam and the New World Disorder. California: University of California Press, 1998.

Tracy, David. Plurality and Ambiguity; Hermeneutic, Religion, and Hope. Chicago: University of Chicago Press, 1987.

Zada, Hamami. "Agama dan Etnis: Tantangan Pluralisme di Indonesia." in Sururin and Maria Ulfa (eds). Nilai-Nilai Pluralisme dalam Islam. Jakarta: Nuansa-Fatayat NU-Ford Foundation, 2006.

Zainuddin, M. "Pluralisme dan Dialog Antaragama." in Journal of Media Philosophica-Theologia. 5, 1 (March 2005).

\section{Internet Sources}

http:/ / www.tabloidpodium.com/berita-catatan-the-wahid-instituttentang-kebebasan-beragama.html. 